Kohl: a Journal for Body and Gender Research

Vol. 1, No. 2 (Winter 2015)

\title{
The Erotic, the Exotic, and the Space(s) In Between: The Race for Feminist Waves
}

Ghiwa Sayegh 
In "Uses of the Erotic: The Erotic as Power," ${ }^{1}$ Audre Lorde defines the erotic as a resourceful site of deep and intimate feminine power. Black feminists and feminists of color have long since joined Lorde to protest their marginal positions and reclaim their histories as matrilineal, different, and abundant. But why do we speak of Lorde's erotic in contexts that are geopolitically foreign to African-American feminist struggles? Why do we scrutinize and reimagine aspects of our everyday life through the lens of the erotic?

Less than a decade ago, when the young(er) feminist movements I was part of were still burgeoning, their first stutters wanted to articulate and bridge multiple aspects of discrimination: refugees, workers, women, trans, Palestine, ethnic minorities... Our potpourri of struggles was first sneered at by partisans of the "human rights" liberal discourse. It was widely underdocumented as well, but it still is in our oral history. Suddenly, Crenshaw's intersectionality ${ }^{2}$ made sense, and as outsiders, we invoked Lorde's erotic sisterhood.

So how does the erotic apply in our contexts? We seem to always be construed as standing on either side of dichotomies: self/other, West/East, good/bad Arab, etc. The erotic refuses to be given that choice. It is sexual, of course, but it especially holds the power to imagine, to resist, to write history, and to produce erotic knowledge from a source of brown feminist dissent. The erotic does not belong to a specific feminist "wave," as it does not subscribe to universalized scales and linear accounts of history. However, it retains the property of waves - untamable and in constant motion.

It is perhaps because of its capacity to be and be untamable that the erotic is exploited by internal narratives of shame, respectability, and morality that are attributed to our "culture" and traditions. This dissociation of the personal from the political oppresses marginalized groups even further by distancing them from their erotic power. Simultaneously, it is my feeling that the question of feminist "waves" contributes to the exploitation of the erotic. ${ }^{3}$ We are perceived as stalling, and we feel the pressure to "catch up." As we pant and puff behind, we tend to forget that when De Beauvoir was writing her Second Sex, brown women were putting their own bodies on the frontline of resistance. They led riots and fought for the rights of factory workers, fishermen, and farmers (Kaedbey 2014). Coupled with conventional values, the race for waves exoticizes us.

The exotic, then, is one particular way of perceiving the exploitation of the erotic; it reduces the erotic to a space of brown misrepresentation and discrimination. Whether stemming from internal dynamics of power or foreign appropriations, the exotic reinforces consumerist and fundamentalist politics in the MENA regions. Its distortion of the erotic becomes interwoven with the objectification of women, the reproduction of reductive brown and black femininities/masculinities, and the sensationalization of queer identities and lives. Most

\footnotetext{
1 Lorde, Audre. "Uses of the Erotic: The erotic as Power." Sister Outsider: Essays and Speeches. Freedom, CA: Crossing Press, 1984. 53-59.

${ }^{2}$ Crenshaw, Kimberlé. "Demarginalizing the intersection of race and sex: a black feminist critique of antidiscrimination doctrine, feminist theory and antiracist politics." University of Chicago Legal Forum 140 (1989): 139-167.

${ }^{3}$ My co-editor, Deema Kaedbey, problematizes the issue of feminist waves at length in her PhD thesis, Building Theory Across Struggles: Queer Feminist Thought in Lebanon (2014). Part of her thesis on the topic of waves can be read in Sawt al Niswa, under Shadow Feminism in Lebanon, Part One.
} 
disturbingly, exploiting the erotic is a foundational aspect of hegemonic knowledge production: it alienates women and feminist writings by removing them to the sidelines, thus locking them into a polarized binary of center/margin.

Departing from the notion that the personal is political, this issue of Kohl: a Journal for Body and Gender Research looks at the non-exotic erotic, or the erotic unhinged. It engages with exoticized representations of brown bodies and voices of dissent, but it especially articulates our erotic (re)imaginations and resistance. As we speak or write, the erotic is being reclaimed by women, feminists, and queer people as a means of survival, pleasure, and change.

The issue opens with Cynthia El Khoury's opinion piece, "Curse Words: The Language of (Hetero)Intimacy." El Khoury takes us on a tour of the innumerable swear words that feature the word "cunt" and that populate our Arabic language. She takes a delectable detour to reimagine the Ottoman origins of the word "cunt." By drawing on her experience as a sexual health trainer and policymaker, El Khoury connects language, anatomy, and art together, ushering us into deconstructing the power of words and intimacy in legal and linguistic systems of heterosexism.

El Khoury's fiddling with the many facets of the word "vagina" paves the way for Lady Gya's "The Hystory of My Vagina: A Manifesto," a poignant testimony about her sexual organ in all its states. The manifesto documents its hystory with a "y," to illustrate the shift from oral to written transmission of matrilineal histories. Sharp, unnerving, and raw, it guides the reader into rediscovering the vagina from a personal/political place.

In line with the themes of vaginas, art, and matrilineal transmission, "Openings" is back with two different pieces. The first one, "Of Periods, Bodies, and Desire: A Discussion on the Erotic Image in Artistic Representations," is a discussion between Mawn, Amanda, and Sarag, facilitated by Rebecca Saab Saadeh. Exploring their own work, the three non-artists grapple with the notions of menstruation, sexual organs, and images and imagination. They unearth the erotic and its definitions from within the various mediums of artistic representations. The second "Openings" piece is an interview I conducted with Jessika Khazrik over Skype. "Sex Tourism and the Military in Biomythographic Performances: An Interview with Jessika Khazrik" enquires into the linkages between sex tourism in former colonies and the military institution. It parallels the feminist sex wars with the Lebanese civil war, and revisits history from a perspective of "burning" women writings. By reclaiming biomythography as a performative trope, the interview taps into the similarities between Khazrik's own skin and her mother's photographs, thus infusing the visual/digital mediums with eroticism.

Still in the spirit of women writings and (auto)biographies, Salma Shash gives us this issue's first article, "Battles with Desire: Centering the Body in the Personal Narratives of Doria Shafik and Latifa El-Zayyat." Shash rereads the two Egyptian women activists' biographies by positioning the female body as a tool of resistance to oppressive political systems. Most strikingly, she reminds us that subverting gendered and sexual norms is not the only way to put our bodies on the frontline and to stand against the nationalist and oppressive regimes that sprung up with the post-independence Egyptian era. 
Looking into a different genre of female writing, Ghadir K. Zannoun marvels us with the magical realism of Fatma: A Novel of Arabia by Saudi Arabian author Raja Alem. "Fantasy, Mysticism, and Eroticism in Raja Alem's Fatma" reads into the layers of eroticism in the novel, which resonate with Audre Lorde's definition of the erotic. With Zannoun, the borders of fantasy and realism, mysticism and rationalism, and corporeality and transcendence fade away. They give way to a new means of addressing patriarchal binaries by validating myth as a form of feminist writing.

With "A Muffled Scream: Queer Affects in Abdellah Taïa's Salvation Army," Dina Georgis delves into another form of erotic representation of desire. The Moroccan writer and filmmaker's movie exposes queer epistemologies as nonconforming to the widely accepted definitions of "gay." While the protagonist's sexuality could be read as homonormative, Georgis complicates queer affects by destabilizing the equation of queer liberation as a colonial enterprise. Her analysis weaves mourning with onscreen silence, prompting us to grasp the uneasiness behind polarized affects.

Sarah Hamdan is back with "Becoming-Queer-Arab-Activist: The Case of Meem," an article that echoes Georgis' deconstruction of superficial subjectivities. Departing from a Deleuzian reading of becoming, Hamdan delineates non-identitarian approaches as nomadic. Her close reading of a conversation between former members of Meem falls within the broader discussions of macro- and micropolitics of location. Hamdan challenges both the exoticism behind the Gay International and the Westernized context of its critics. Instead, she locates the non-linearity of "different difference" in Lorde's erotic.

Another case study that complicates the East/West binary is that of Egyptian Aliaa Elmahdy, or known as the nude blogger. In "From Ideology to Dogma? A discussion about Femen, Aliaa Elmahdy, and Nudity in the Arab World," Maya El Helou immerses herself in the debates that took place among local feminists after Elmahdy posted of a nude picture of herself and joined Femen. While some validated nudity as a Western import, El Helou reclaims nude protesting as embedded in our feminist history. Most importantly, she cautions against a dogmatic reading of feminism that would quantify our struggle.

In another critique of petty dogmatism, Sanaa Khoury reviews The Third Sex: what Plato told me on his deathbed, the latest book of Joumana Haddad. Mirroring Haddad's Beauvoirian (mis)appropriation, Khoury wittingly names her commentary "One Is Not Born, But Rather Becomes, Joumana." Her tragicomic tone walks us through Haddad's unfortunate distortion of the term "third sex." She ponders on Haddad's contradictory assumptions and her insistence on creating new philosophies, such as the "Humanus," which pretend to come in a narcissistic vacuum. A must read.

Finally, our resource section features Zouhair Gassim's "Genre et éducation sexuelle dans le système éducatif marocain," or "Gender and Sexual Education in the Moroccan Educational System." Gassim gives us Kohl's first French publication. His resource carefully dissects the Moroccan scholastic curricula, which often ignores the social, psychological, and emotional dimensions of gender and sexuality education, thus contributing to the crystallization of heterosexist systems of thought. 
Against all odds, Kohl is out for the second time this year. Once again, we feel compelled to write back as a legacy and a debt to those that precede us and those who come after us. Many would perceive this act of writing as an untimely endeavor. Many more would condemn the crude images and subjects that this issue uncovers. But some of us are always unapologetically brave. ${ }^{4}$

\footnotetext{
${ }^{4}$ Borrowed from: Hull, Gloria T., Bell-Scott, Patricia, and Smith, Barbara. All the Women Are White, All the Blacks Are Men, But Some Of Us Are Brave: Black Women's Studies. Feminist Press, 1982.
} 